\title{
CHURCH HISTORY: AN INTRODUCTION TO RESEARCH METHODS AND RESOURCES
}

Bradley, J.E. and Muller, R.A.

2016. Second edition. Grand Rapids: Eerdmans. 293 pages, ISBN 9780802874054.

\section{Reviewed by Erna Oliver}

Department of Christian Spirituality, Church History and Missiology

University of South Africa, Pretoria

olivee@unisa.ac.za

The one thing I struggle most with as a lecturer in Church History is research methodology; and an excellent book on this topic will be of great value to undergraduate students. Although the title of this book gives the impression that this could be the answer to the quest for such a book, it is not. The first chapter, dealing with the definition of terms, a summary of the development of church historiography and the methods and models for research as well as the distinction and connection between intellectual, political and social history, is crammed into only 30 pages which account for 10 per cent of the content.

The other two aspects of the title are, however, well represented in the work. This book is indeed an introduction to the study of church history and provides the reader with a good summary on how to use and evaluate historical sources. Full chapters are devoted to the initial stages of doing research, using primary sources to do research, the practice of doing research, and the craft of writing history. A short chapter advises on the preparation of lectures, article writing and the compilation of a monograph. The two well-known authors effectively persuade the reader of the importance of studying the history of the church. The importance of history lies in the identification and definition of issues on the one hand, and of the cultivation of objectivity in judgement on the other hand (p.58).

Since the first edition in 1995, the world has become digital and this is well captured in the second edition. Listed sources have been extensively expanded and a new section on World Christianity was added. However, the main focus is still on England and America, which limits its usefulness for students on the African continent.

I agree with the words of the Christian Century that stated the following regarding the first edition: "While Bradley and Muller show how hard it is to learn the craft, they

\section{UNISA $\approx$}


help the apprentice considerably." This is why the book is highly recommended for undergraduate students in theology who need to understand that church history is the mother and origin of all theology disciplines and the broad foundation of theology. It will provide them with a general introduction to the subject of church history, warn them about pitfalls, educate them on the use of sources, and provide useful tips on how to report on their research findings. 